\title{
Scenarios and Pathways of Radionuclide Releases from Near-Surface Waste Disposal Facilities: A Brief Overview of Historical Evidence
}

\author{
- Bugai Dmitri, PhD (Phys. \& Math.) \\ Institute of Geological Sciences, Kyiv, Ukraine \\ ORCID: http://orcid.org/0000-0002-2404-5639
- Avila Rodolfo, $\mathrm{PhD}$
AFRY, Stockholm, Sweden

The very low-level waste (VLLW) produced during decommissioning of nuclear facilities can be suitable for disposal in landfill type facilities. Considering the similarities in design, the experience gained in nearsurface disposal of radioactive waste in trenches and vaults is relevant to the issue of VLLW disposal in landfills. This paper presents a brief review of internationally reported cases of radionuclide releases from near-surface disposal facilities. Based on this review, the conclusions are made that the following radionuclide release and exposure scenarios should be accounted for in safety assessment of VLLW disposal in landfills: i) leaching from waste to groundwater by atmospheric precipitations; ii) bath-tubing scenario; iii) scenarios caused by extreme meteorological and hydrological events (erosion, flooding, etc.); iv) human intrusion. The gaseous transport deserves attention for a number of relevant radionuclides, such as (C-14, Rn-222, etc.). In addition, the possibility of early degradation of engineered containment structures (soil covers, bottom seals) should be cautiously considered.

Keywords: VLLW, waste disposal, landfills, safety assessment, exposure scenarios.

(c) Bugai D., Avila R., 2020

\section{Introduction}

The decommissioning of nuclear power reactors and other nuclear facilities will generate large amounts of very low-level waste (VLLW) across the world [1]. Generally, radioactive waste should be managed in a way that is consistent with safety standards and national regulations and the solution chosen should reflect the level of hazard and longevity of the waste [2]. Due to low activity concentrations and consequently low radiological hazard, the VLLW is suitable for disposal in simple landfill type facilities [3], [4].

Disposal of VLLW in landfills has much in common with early "atomic age» (1940s-1960s) practices of shallow burial of radioactive waste. At that time, a widely used approach worldwide was to dispose non- stabilized «bulk» waste in soil trenches. These trenches often lacked proper hydro-isolation of their capping and bottom. In the Soviet Union and some Eastern Bloc countries, the low-level waste was disposed in 1960s-1990s in so-called «RADON facilities» that consist of near-surface concrete vaults lined with the hydraulic isolating materials and capped with concrete slabs, clay and asphalt layers.

Considering the similarities in design, the experience gained in near-surface disposal of radioactive waste in trenches and vaults is relevant to the issue of VLLW disposal in landfills. There are documented cases where the transfer of radionuclides from near-surface radioactive waste disposal facilities to the environment has caused contamination of soils and groundwater, which required implementation of costly remedial measures. It is therefore important 
to account for «lessons learned» from management of the near-surface waste disposal facilities when planning VLLW disposal in landfills.

This paper presents a review of cases of radionuclide releases from near-surface radioactive waste disposal facilities that have led to contamination of environmental media (groundwater, surface water, soil) with potential risks of human exposure. The objective is to identify, based on this historic experience, the important radionuclide release mechanisms and exposure pathways, as well as radionuclides that potentially represent the main source of concern. This experience can inform future safety assessment analyses of VLLW disposal in landfills .

\section{Overview of radionuclide release mechanisms and exposure pathways}

The reviewed cases of radionuclide releases from near-surface disposal facilities are summarized in Table 1.

Table 1 - Historic cases of radionuclide releases to the environment from near-surface disposal facilities for radioactive waste

\begin{tabular}{|c|c|c|c|c|}
\hline $\begin{array}{l}\text { Country, waste } \\
\text { disposal site }\end{array}$ & \begin{tabular}{|l} 
Type of waste \\
disposal facility
\end{tabular} & $\begin{array}{l}\text { Radionuclide release/ } \\
\text { exposure pathway }\end{array}$ & $\begin{array}{l}\text { Radionuclides of } \\
\text { primary concern }\end{array}$ & References \\
\hline \multicolumn{5}{|l|}{ Australia } \\
\hline $\begin{array}{l}\text { Little Forest, Lucas } \\
\text { Heights }\end{array}$ & Unlined soil trench & $\begin{array}{l}\text { Groundwater contamination; } \\
\text { Bath-tubing }\end{array}$ & $\begin{array}{l}\mathrm{H}-3 ; \\
\mathrm{Pu}-239,240\end{array}$ & \begin{tabular}{|l}
{$[5]$} \\
{$[6]$}
\end{tabular} \\
\hline \multicolumn{5}{|l|}{ Canada } \\
\hline $\begin{array}{l}\text { Chalk River } \\
\text { Laboratories }\end{array}$ & Unlined soil trench & $\begin{array}{l}\text { Groundwater, surface water } \\
\text { contamination }\end{array}$ & Sr-90, H-3, C-14 & $\begin{array}{l}\text { [7], [8, Annex II], }[9, \\
\text { Appendix A.3] }\end{array}$ \\
\hline \multicolumn{5}{|l|}{ France } \\
\hline $\begin{array}{l}\text { Centre de la } \\
\text { Manche }\end{array}$ & Concrete trenches & $\begin{array}{l}\text { Groundwater, surface water } \\
\text { contamination }\end{array}$ & $\mathrm{H}-3$ & [9, Appendix A.6] \\
\hline \multicolumn{5}{|l|}{ Lithuania } \\
\hline Maisiagala RADON & Concrete vault & Groundwater contamination & $\mathrm{H}-3$ & [9, Appendix A.9] \\
\hline \multicolumn{5}{|l|}{ United Kingdom } \\
\hline Drigg & Unlined soil trench & Groundwater contamination & $\mathrm{H}-3$ & [10] \\
\hline \multicolumn{5}{|l|}{ Ukraine } \\
\hline Kyiv RADON & Concrete vault & $\begin{array}{l}\text { Bath-tubing, } \\
\text { Groundwater contamination }\end{array}$ & $\mathrm{H}-3$ & $\begin{array}{l}\text { [9, Appendix A.14], } \\
{[11]}\end{array}$ \\
\hline Kharkiv RADON & Concrete vault & Groundwater contamination & $\mathrm{H}-3$ & {$[9$, Appendix A.14] } \\
\hline $\begin{array}{l}\text { Chornobyl Zone, } \\
\text { Red Forest }\end{array}$ & Unlined soil trench & $\begin{array}{l}\text { Groundwater contamination } \\
\text { (high groundwater table); } \\
\text { flooding; bio-migration } \\
\text { (uptake by plants) }\end{array}$ & $\begin{array}{l}\text { Sr-90; } \\
\text { Cs-137 (bio- } \\
\text { migration) }\end{array}$ & {$[12],[13],[14]$} \\
\hline Pisky-1, Kyiv Region & Unlined soil trench & Intrusion (small excavation) & Cs-137 & [15] \\
\hline \begin{tabular}{|l} 
Veselovsky Site, \\
Kirovohrad Oblast
\end{tabular} & Unlined soil trench & $\begin{array}{l}\text { Intrusion (using excavator } \\
\text { equipment) }\end{array}$ & Cs-137 & [16] \\
\hline \multicolumn{5}{|l|}{ USA } \\
\hline Barnwell, SC & Unlined soil trench & Groundwater contamination & $\mathrm{H}-3$ & [9, Appendix A.15] \\
\hline $\begin{array}{l}\text { Idaho National } \\
\text { Engineering } \\
\text { Laboratory }\end{array}$ & Unlined soil trench & 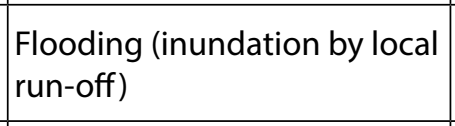 & & [17] \\
\hline Maxy Flats, KN & Unlined soil trench & $\begin{array}{l}\text { Bath-tubing; } \\
\text { Groundwater contamination } \\
\text { (complex hydrology) }\end{array}$ & $\mathrm{H}-3$ & $\begin{array}{l}\text { [9, Appendix A.15], } \\
{[17],[18]}\end{array}$ \\
\hline $\begin{array}{l}\text { Oak Ridge National } \\
\text { Laboratory }\end{array}$ & Unlined soil trench & $\begin{array}{l}\text { Groundwater contamination } \\
\text { (high groundwater table) }\end{array}$ & & [17] \\
\hline Sheffield, IL & Unlined soil trench & $\begin{array}{l}\text { Groundwater, surface water } \\
\text { contamination; } \\
\text { Erosion (run-off from snow } \\
\text { accumulation); Gas transport }\end{array}$ & $\mathrm{H}-3, \mathrm{C}-14$ & $\begin{array}{l}{[17],} \\
{[9, \text { Appendix A.15] }} \\
{[25]}\end{array}$ \\
\hline West Valley, NY & Unlined soil trench & \begin{tabular}{|l|} 
Bath-tubing \\
Gas transport
\end{tabular} & & $\begin{array}{l}{[17]} \\
{[25]}\end{array}$ \\
\hline
\end{tabular}


The most frequently encountered problem is groundwater contamination following radionuclide leaching from the radioactive waste disposal sites (Table 1). Such problems have been attributed to inadequate attention to site-selection criteria, inadequate site characterization and improper engineered design. Examples of factors that increase risks of groundwater contamination are humid climate and high groundwater table, «bath-tubing» effect (accumulation of water in trench or vault), trench cap integrity problems, and hydrologic and geochemical complexity of the site (not captured by conceptual site model and not addressed by engineered design of the waste disposal site) [17]. The above listed factors are often interrelated and interdependent.

Humid climate and high groundwater table conditions were encountered, for example, in Oak Ridge, West Valley (USA), and in Chornobyl Red Forest (Ukraine) [12], [14], [17]. The high groundwater table conditions resulted in (seasonal) submergence of waste and leaching of radionuclides to groundwater. In Chalk River Laboratories (Canada), intensive radionuclide migration to groundwater from trenches dug in sand overburden was increased by high atmospheric precipitation rates, and by capping by a high-permeability sandy soil with poor hydraulic isolation capacity [8, Annex II], [9, Appendix A.3].

The «bathtub effect» occurs when a trench or vault is in a low-permeability geological formation and accumulates meteoric water (usually due to trench cap integrity problems). In some instances, the water accumulated in the trench may periodically seep out on the ground surface carrying leached radionuclides. This type of radioactivity release mechanism occurred, for example, in the Maxey Flats (USA) where trenches were dug in low-permeability shale, while trench capping lost integrity due to subsidence and desiccation cracks [17], [18].

Another well-documented case of bathtubbing is the Little Forest Site (Australia) [6]. Based on monitoring observations carried out on the site, the water level in the trenches (dug in low-permeability clay and shale layer) responded quickly to rainfall and intermittently reached the surface, resulting in the saturation and overflow of the trenches during extreme rainfall events, causing surface contamination by Pu-239,240 from the trench contents.

Accumulation of water in the bottom part of the vault (without overflow of the storage cell) was observed in one of the vaults of Kyiv RADON (Ukraine). This was attributed to condensation of water inside the vault and/or penetration of meteoric water through the partially degraded concrete capping of the vault [9, Appendix A.14]. Subsequent leakage of radioactivity through the imperfect bottom lining of the vault resulted in a large tritium plume in groundwater near the facility with $\mathrm{H}-3$ concentration reaching $1 \mathrm{E} 7 \mathrm{~Bq} / \mathrm{L}$ (as in 2003) [11]. Leakage of tritium to groundwater was observed also at Kharkiv RADON (Ukraine) and Maisiagala RADON (Lithuania) [9, Appendix A.9, A.14]. Studies carried out at Moscow RADON (Russia) have shown that degradation of multi-barrier system integrity has occurred during several decades of operation of the waste vault [9, Appendix A.11]. The waterproof properties of the upper clay liner have degraded (permeability of clay has increased from $1 \mathrm{E}-8-1 \mathrm{E}-9 \mathrm{~m} / \mathrm{d}$ to $1 \mathrm{E}-6 \mathrm{~m} / \mathrm{d}$ ) and cracking of the concrete surface of the repository was observed.

The «hydrologic and geochemical complexity» problem means that the disposal site is physically and chemically more complex than originally anticipated during the design phase. For example, it appeared that groundwater flow at the Maxey Flats is controlled by fractures. This gave rise to a fast-preferential radionuclide migration pathway in the generally lowpermeability shale deposits. This caused groundwater contamination by tritium and other radionuclides [17]. Because of variety and complexity of low-level waste and ambient geochemical conditions (influenced, for example, by the co-disposed chemical waste or by degradation of organic materials inside the trenches), the radionuclide speciation in leachate solution can be complex and difficult to predict. This can result in facilitated transport of generally low mobile radionuclides such as actinides and Cs-137 in the form of complexed neutral or anionic species or colloids [19]. High mobility of small amounts of Pu isotopes likely promoted by the discussed above geochemical factors has been observed at the Maxey Flats [17], [18] and in the Chornobyl Red Forest [20].

Though less common than radionuclide leaching by infiltrating meteoric water, problems caused by erosion of protective soil cap and by flooding by surface water of soil trenches also have been reported in the literature. These cases are usually related to unusual/extreme meteorological and hydrological events. For instance, unanticipated rapid run-off from large snowmelt accumulation caused erosion problems at Sheffield (USA) [17]. Similarly, very large snowmelts in spring 2005 caused flooding of waste trenches in the Chornobyl Red Forest.

Important radionuclides for the groundwater pathway

By far, the most widespread cases of groundwater contamination from waste disposal facilities are caused by tritium releases (Table 1). Once released from the source, this radionuclide is not retarded by engineered barriers and geological materials and is transported in the aquifer at groundwater flow velocity. At the same time, tritium has relatively low radio-toxicity (World Health Organization guidance level for tritium in drinking water is $10000 \mathrm{~Bq} / \mathrm{L}$ ) and a short decay half-life of 12.3 years. Therefore, 
tritium releases to subsurface usually does not pose significant risks to human and the environment. Another radionuclide that is often abundant in radioactive waste source-terms and has relatively high mobility in subsurface environments is $\mathrm{Sr}-90$ (half-life 30.1 years; WHO drinking guideline $10 \mathrm{~Bq} / \mathrm{L}$ ). In the sandy aquifers in the Chalk River Laboratories (Canada) and Chornobyl site, Sr-90 usually migrates at $\sim 10 \%$ to several percent of groundwater velocity [8, Annex II], [12]. This radionuclide is considered as the radioactive contaminant of primary concern for the groundwater pathway on these sites. High mobility of Sr-90 in the subsurface has been observed also in Sellafield (UK) [21] and Hanford (USA) [22]. On several sites, groundwater contamination by radiocarbon (C-14; half-life 5370 years; drinking WHO guideline $100 \mathrm{~Bq} / \mathrm{L}$ ) has been reported. This radionuclide can be present in groundwater in relatively mobile negatively charged inorganic carbonate species (e.g., $\left.\mathrm{HCO}_{3} \mathrm{CO}_{3}{ }^{2-}\right)$ ), as well as in the form of mobile organic compounds [7], [23]. Process leading to C-14 attenuation in groundwater include calcite precipitation, isotopic exchange with the solid matrix of aquifer rocks and microbial degradation of carrier organic molecules [23], [24]. At the Chalk River Laboratories, the $\mathrm{C}-14$ concentrations in groundwater were much lower than those of Sr-90 and H-3 [8, Annex II].

It should be noted that, to our knowledge, none of the radionuclide leakages to groundwater or surface water from facilities listed in Table 1 has been harmful to human health. The contaminated water has either not been used for drinking or other purposes that could cause exposure of humans, or contaminant concentrations have been below drinking water standards. In some cases, additional buffer zones have been created around the contaminated sites to prevent exposure of the public, for example, in the Maxey Flats and Sheffield, the USA [9, Appendix A.15]. In the Chalk River Nuclear Laboratories and in Chornobyl Zone, the use of contaminated groundwater by the public is not practiced because of institutional control of the land, comprising waste disposal facilities and contaminated aquifers. Radionuclide leakages to groundwater have led however to costly remediation projects. These have included installation of enhanced trench caps on old trenches (Barnwell, Maxey Flats, Sheffield, West Valley, the USA; Chalk River Laboratories, Canada; Drigg, the UK). Retrieval of waste has been carried out in some early unlined trenches in the Chalk River Laboratories (Canada) and Centre de la Manche (France). Retrieval and re-disposal of waste from leaking vaults is planned on several RADON facilities, including Kyiv RADON. For containment of Sr-90 plumes, «pump and treat» operations as well as cut-off walls and absorbing subsurface barriers are currently used in the Chalk River Laboratories [9, Appendix A.3].

\section{Transport of radioactive gases}

Land burial of radioactive waste can potentially result in transport of radioactive gases produced from biological degradation of waste, chemical reactions, radioactive decay, etc. to the atmosphere or to the groundwater. This mechanism can be of importance for a number of radionuclides such as $\mathrm{C}-14, \mathrm{H}-3, \mathrm{Rn}-222$ and Rn-220 [25]. In particular, the gaseous transport from LLW waste disposal sites is considered to be a pathway of importance for C-14 [25], [26]. The interest to C-14 transfer from the soil source-term to atmosphere has been fostered recently by safety assessment of geological disposal of radioactive waste [26], [27].

In case of waste activity inventory containing Ra-226 or Th-232, the diffusion to atmosphere of progeny radioactive gases $\mathrm{Rn}-222$ and $\mathrm{Rn}-220$, respectively, can be an issue. The radon dispersion in atmosphere from NORM sites containing uranium ore residues is a well-known problem [28] (though the NORM sites generally differ essentially in size, inventory and design from radioactive waste disposal sites and landfills, so that analogies in this case should be cautious).

The literature data on gaseous releases from nearsurface waste disposal facilities are rather scarce. This can be partially due to insufficient attention and difficulties in measuring such releases. Presence of $\mathrm{C}-14$ and $\mathrm{H}-3$ in gaseous phase in the form of $\mathrm{C}-14 \mathrm{O}_{2}$, $\mathrm{H}-3$-water vapor, $\mathrm{C}-14$ and $\mathrm{H}-3$-methane, -ethane, -propane and -butane, as well as $\mathrm{Kr}-85$ and $\mathrm{Rn}-222$ has been reported at radioactive waste disposal sites in Sheffield, IL and West Valley, NY, USA [25], however the cited review paper does not provide details on the release rates to atmosphere and associated radiological impacts. Despite limited historic data, the discussed gaseous pathway for the relevant radionuclides deserves attention and evaluation in waste disposal safety analyses.

\section{Human intrusion}

Radionuclide releases from a waste disposal site and exposure of the public might be caused by «human factor». This type of scenario is referred in the literatures as «human intrusion scenario». Human intrusion can occur following societal perturbations resulting in the weakening of institutional control or even full loss of societal memory about the waste site. Table 1 lists two examples of such scenarios, which have occurred in Ukraine following the disintegration of the Soviet Union in 1991. One of the discussed sites is the Pisky-1 burial site in Kyiv Oblast (Ukraine) containing waste contaminated with Cs-137 originating from the Chornobyl fallout. The waste was generated resulting 
from clean-up operations in the local village carried out in 1987-88. A field visit to this site in April 2016 revealed that the soil cover of the trench was ruined by recent excavations, which were evidently created by scrap metal hunters, searching for metal pieces inside the trench (such as sheets of roof metal etc.). The dose rate in the excavations reached $\sim 6-7 \mu \mathrm{Sv} /$ hour. The fence and radiation danger signs (initially present on the site) were looted during the 30 years that have passed since the Chornobyl accident [15].

Another example is the "Veselovsky Pit» Legacy trench site situated near the City of Kropyvnytsky (Ukraine). This site was inadvertently discovered in July 2017 by local scrap metal hunters who had found and excavated several steel objects and containers [16]. It turned out that the metal and contents of containers were radioactive. Subsequent archive search established that this waste burial site was established in 1988. It contained waste from the clean-up of the consequences of a radiation accident at one industrial enterprise in the Kropyvnytsky City, where an industrial Cs-137 source was destroyed. In total 224 containers with Cs-137 contaminated waste were buried in a clay pit outside the city. In the subsequent period, the memory about this site waste was lost. By 2017, there was no physical protection of the site or radiation danger signs.

Considering the discussed above «negative» experiences of land disposal of radioactive waste observed in early periods, the siting process and near-surface radioactive waste disposal practices at operational sites have been essentially modified to ensure better isolation of radioactive waste. Greater emphasis is put on stable waste forms and on reliable engineered containment [9].

\section{Engineered barriers for waste disposal in landfills}

As noted in [29], «in the area of near-surface radioactive waste disposal as well as landfilling in the conventional waste management area, the needs for knowledge and for pertinent strategies with regard to long term safety may be rather similar». Similarly to radioactive waste disposal facilities, the long-term behavior of landfill depends on the physical and chemical evolution of waste and on the performance of engineered barriers.

In conventional landfills, confinement of waste from the environment is ensured by engineered soil covers and bottom seals. These liners frequently employ the following materials: geo-membranes made of high-density polyethylene (HDPE) or polyvinyl chloride (PVC); geo-synthetic clay liners (GCLs) that consist of a thin layer of bentonite sandwiched between two geotextile sheets that are held together by needle punching or stitching; natural clay.
Though the listed above confining barriers employ commonly used technologies, knowledge of their performance is based on relatively shortterm tests, and their long-term evolution and performance (on a scale of decades or hundreds of years) in field conditions is rather uncertain. The HDPE geo-membranes may undergo degradation due to oxidation, extraction, ultraviolet degradation, and thermal degradation. Stress corrosion and brittle behavior under a load over long times can be also an issue [29], [30]. The GCLs and natural clay liners can suffer from ion-exchange process, dehydration, root penetration and cracking leading to significant increase in their hydraulic conductivity [31]. The hydraulic parameters of covers are usually also sensitive to possible differential settlements of the underlying waste. The available literature on sampling and testing of the engineered covers of existing landfills (performed from 3 to 4 years following their installation) provides examples of both earlier than expected geo-liner degradation [31] and of proper performance of the GCL liners foreseen by the landfill project design [32].

In many countries, for example in Sweden, there is a ban on landfilling of organic materials in conventional waste landfills. The bulk of the waste disposed is composed of inorganic waste and ash from incineration of organic domestic waste. This practice creates generally favorable (less reactive) geochemical conditions inside the landfills and minimizes subsidence risks. For example, no cases have been reported so far in which the conventional landfill covers, constructed in Sweden in accordance with modern legislation and standards, have failed. However, such installations are quite new, and cover and liner defects can be difficult to detect [29].

\section{Conclusions}

The following radionuclide release and exposure scenarios based on historic experiences of nearsurface disposal of radioactive waste are relevant to VLLW disposal in landfills to summarize the literature review presented above:

Leaching from waste to groundwater and surface water caused by atmospheric precipitations;

Bath-tubing scenarios;

Scenarios caused by extreme meteorological and hydrological events (erosion, flooding, etc.)

Human intrusion.

For a number of relevant radionuclides, such as (C-14, Rn-222, etc.), the gaseous transport deserves attention. Considering known historic instances of failure of engineered barriers of near-surface disposal facilities for radioactive waste and the limited knowledge of long-term behavior of geo-membranes and geo-synthetic liners, it should be cautiously 
considered, in safety assessments of VLLW disposal in landfills, the possibility of early degradation of engineered containment structures (soil covers, bottom seals).

While the listed above scenarios have been often identified as the relevant ones in the literature on safety assessment for near-surface radioactive waste disposal facilities, their justification usually employs FEP (features, process and events) analysis (i.e., theoretical approach) [31], [32]. This review further confirms the importance of the listed above scenarios based on historical evidence from past waste disposal practices.

\section{ACKNOWLEDGEMENTS}

Preparation of this review was supported by the research project SSM2019-899 funded by the Swedish Radiation Safety Authority (SSM) and by research theme No. III-11-20 of the National Academy of Sciences of the Ukraine.

\section{References}

1. IAEA-TECDOC-1572 (2007). Disposal aspects of low and intermediate level decommissioning waste. (Results of a coordinated research project 2002-2006). International Atomic Energy Agency, Vienna, 153.

2. GSR Part 3 (2014). Radiation protection and safety of radiation sources. General Safety Requirements Part 3, International Atomic Energy Agency, Vienna, 477.

3. Seher, H., Navarro, M., Artmann, A., Larue, J., Roloff, R., Weiß, D. (2016). Modelling contaminant transport in generic landfills for decommissioning waste from German nuclear power plants. Progress in Nuclear Energy, 89, 46-56. doi: 10.1016/j.pnucene.2016.01.015.

4. Poškas, P., Kilda, R., Šimonis, A., Jouhara, H., Poškas, R. (2019). Disposal of very low-level radioactive waste: Lithuanian case on the approach and long-term safety aspects. Science of the Total Environment, 667, 464-474. doi: 10.1016/j.scitotenv.2019.02.373.

5. Hughes, C., Cendon, D., Harrison, J.J., Hankin, S.I., Johansen, M.P., Payne, T.E., Vine, M., Collins, R.N., Hoffmann, E.L., Loosz, T. (2011). Movement of a tritium plume in shallow groundwater at a legacy low-level radioactive waste disposal site in eastern Australia. Journal of Environmental Radioactivity, 102(9), 43-52. doi:10.1016/j.jenvrad.2010.05.009.

6. Payne, T. E., Harrison, J. J., Hughes, C. E., Johansen, M. P., Thiruvoth, S., Wilsher, K. L., Cendón, D. I., Hankin, S. I., Rowling, B., \& Zawadzki, A. (2013). Trench "bathtubbing" and surface plutonium contamination at a legacy radioactive waste site. Environmental Science \& Technology, 47(23), 13284-13293. doi:10.1021/es403278r.

7. Killey, D., Rao, R., Eyvindson, S. (1998). Radiocarbon speciation and distribution in an aquifer plume and groundwater discharge area, Chalk River, Ontario. Applied Geochemistry, 13, 3-16. doi: 10.1016/S0883-2927(97)00048-6.

8. IAEA-TECDOC-1088 (1999). Technical options for the remediation of contaminated groundwater. International Atomic Energy Agency, Vienna, 129.

9. Technical report series No. 433 (2005). Upgrading of near surface repositories for radioactive waste. International Atomic Energy Agency, Vienna, 137.

10. Warwick, P., Allinson, S., Beckett, K., Eilbeck, A., Fairhurst, A., Russel-Flint, K., Verrall, K. (2002). Sampling and analyses of colloids at the Drigg low level radioactive waste disposal site. Journal of Environmental Monitoring, 4(2), 229-234. doi: 10.1039/B106256P.

11. Scherbak, O., Koshliakova, T., Dolin, V. (2016). Estimation of efficiency of radio-hydrogeological monitoring in the zone of influence of Kyiv radioactive waste storage. Visnyk of Taras Shevchenko National University of Kyiv: Geology, 2(73), 46-52.

12. Dewiere, L., Bugai, D., Grenier, C., Kashparov V., Ahamdach N. (2004). 90Sr migration to the geosphere from a waste burial in the Chernobyl exclusion zone. Journal of Environmental Radioactivity, 74, 139-150. doi: 10.1016/j.jenvrad.2004.01.019.

13. Kashparov, V., Yoschenko, V., Levchuk, S., Bugai, D., Van Meir, N., Simonucci, C., Martin-Garin, A. (2012). Radionuclide migration in the experimental polygon of the Red Forest waste site in the Chernobyl zone - Part 1: Characterization of the waste trench, fuel particle transformation processes in soils, biogenic fluxes and effects on biota. Applied Geochemistry (Special Issue: Chernobyl), 27, 1348-1358. doi: 10.1016/j. apgeochem.2011.11.004

14. Bugai, D., Skalskyy, A., Dzhepo, S., Kubko,Yu., Kashparov, V., Van Meir, N., Stammose, D., Simonucci, C., Martin-Garin, A. (2012). Radionuclide migration at experimental polygon at Red Forest waste site in Chernobyl zone. Part 2: Hydrogeological characterization and groundwater transport modeling. Applied Geochemistry (Special Issue: Chernobyl), 27, 1359-1374. doi: 10.1016/j.apgeochem.2011.09.028.

15. Bugai, D., Gebauer, J., Scior, C., Sizov, A., Burness, S., Retz, Y., Molitor, N. (2019). Safety ranking of Chernobyl radioactive legacy sites situated in populated areas for prioritization of remedial measures. Nuclear Physics and Atomic Energy, 20(1), 34-43. doi: 10.15407/jnpae2019.01.034.

16. The SNRIU investigated the radioactive site in Kropyvnytskyi (Elektrovesti.net, 9 August 2017). Retrieved from https://elektrovesti.net/55150_gosatomregulirovanieissledoval-radioaktivnuyu-territoriyu-v-kropivnitskim.

17. Robertson, J.B. (1984). Geologic problems at low-level radioactive waste disposal sites. Groundwater contamination, Washington, DC, National Academy Press, 104-108.

18. Cleveland, J. M., Rees, T. F. (1981). Characterization of plutonium in Maxey Flats radioactive trench leachates. Science, 212, 1506-1509.

19. Kersting, A. B. (2012). Impact of colloidal transport on radionuclide migration in the natural environment. Radionuclide behavior in the natural environment: Science, implications and lessons for the nuclear industry. Woodhead Publishing Series in Energy No. 42, Cambridge, 384-410.

20. Levchuk, S., Yoschenko, V., Kashparov, V., Van Meir, N., Ardois, C., Bugai, D. (2009). Phenomenon of a fast migration of plutonium radioisotops in ground water: Colloids or soluble form? 
Radioactive Particles in the Environment, Springer Science+Business Media B.V., 157-167. doi: 10.1007/978-90-481-2949-2_9.

21. Groundwater monitoring at Sellafield. Annual data review 2016. Sellafield Ltd., Seascale, Cumbria, UK, 2017. Retrieved from https://assets.publishing.service.gov.uk/ government/uploads/system/uploads/attachment_data/ file/705993/Groundwater_Monitoring_at_Sellafield_-_Annual_ Data_Review_2016.pdf.

22. Hartman, M. J., Morasch, L. F., Webber, W. D. (2007) Summary of Hanford Site Groundwater Monitoring for Fiscal Year 2006, PNNL-16346-SUM, Richland: Pacific Northwest National Laboratory. Retrieved from https://www.pnnl.gov/main/ publications/external/technical_reports/PNNL-16346_SUM.pdf.

23. Boylan, A.A., Stewart, D.l., Graham, J.T., Trivedi, T., Burke, I.T. (2017). Mechanisms of inorganic carbon-14 attenuation in contaminated groundwater: Effect of solution $\mathrm{pH}$ on isotopic exchange and carbonate precipitation reactions, Applied Geochemistry, 85, 137-147. doi: 10.1016/j. apgeochem.2016.12.006

24. Boylan, A.A., Stewart, D.I., Graham, J.T., Burke, I.T. (2018), Behavior of Carbon-14 containing low molecular weight organic compounds in contaminated groundwater under aerobic conditions. Journal of Environmental Radioactivity, 192, 279-288. doi: 10.1016/j.jenvrad.2018.06.016.

25. Striegel, R.G. (1990) Radioactive gases at low-level radioactive waste repository sites. Safe disposal of radionuclides in low-level radioactive waste repository sites: Proceedings of the Low-level radioactive waste disposal workshop, 11-16 July 1987, Big Lake, California. U.S. Geological Survey Circular 1036, 40-44

26. Mobbs, S., Shaw, G. Norris, S., et al. (2013) Intercomparison of models of ${ }^{14} \mathrm{C}$ in the biosphere for solid radioactive waste disposal. Radiocarbon, 55, 814-825. doi: 10.2458/azu_js_rc.55.16223

27. Avila, R., Kovalets, I. (2016) Models of C-14 in the atmosphere over vegetated land and above a surface-water body. SKB R-15-09. Swedish Nuclear Fuel and Waste Management Co. Stockholm, 50.

28. Technical report Series No. 335 (1992). Current practices for the management and confinement of uranium mill tailing, International Atomic Energy Agency, Vienna, 119.

29. Sjöblom, R., Lindskog, S., \& Andreas, L., (2013). Long term aspects of landfilling and surface disposal: lessons learned from nuclear and non-nuclear decommissioning, remediation and waste management. Journal of Earth Sciences and Geotechnical Engineering, 3(3), 35-51. Retrieved from https://www.divaportal.org/smash/get/diva2:982159/FULLTEXT01.pdf.

30. Rowe, R. K., Islam, M. Z., Brachman, R. W. I. (2010). Antioxidant depletion from a high-density polyethylene geomembrane under simulated landfill conditions. Journal of Geotechnical \& Geoenvironmental Engineering, 136(7), 930-939. doi: 10.1061/ASCEGT.1943-5606.0000302.

31. Meer, S. R., Benson, C. H. (2007). Hydraulic conductivity of geosynthetic clay liners exhumed from landfill final covers. Journal of Geotechnical \& Geoenvironmental Engineering, 133(5), 550-563. doi: 10.1061/(ASCE)1090-0241(2007)133:5(550).

32. Touze Foltz, N. (2012). Geosynthetic clay liners: performance and long-term durability. Retrieved from https://geosynt.files. wordpress.com/2012/04/nathalie-touze-foltz-gcl.pdf.
33. IAEA TECDOC-1380 (2003). Derivation of activity limits for the disposal of radioactive waste in near surface disposal facilities. International Atomic Energy Agency, Vienna, 145.

34. Safety assessment methodologies for near surface disposal facilities results of a coordinated research project, Vol.1 Review and enhancement of safety assessment approaches and tools. International Atomic Energy Agency, Vienna, 2004, 408.

\section{Сценарії та шляхи витоку радіоактивних речовин 3 приповерхневих пунктів захоронення радіоактивних відходів: короткий огляд історичних випадків}

\author{
Бугай Д. О. ${ }^{1}$, Авіла Р. ${ }^{2}$ \\ ${ }^{1}$ Інститут геологічних наук, м. Київ, Україна \\ ${ }^{2} \mathrm{AFRY}$, м. Стокгольм, Швеція
}

Дуже низько активні відходи (ДНАВ), що утворюються під час виведення з експлуатації ядерних об'єктів, можуть бути придатними для захоронення на полігонах для побутових та (або) промислових відходів. 3 огляду на схожість конструкції, історичний досвід, накопичений під час поверхневого захоронення радіоактивних відходів в траншеях $\mathrm{i}$ могильниках, $\epsilon$ актуальним для проблематики захоронення ДНАВ на полігонах для відходів. У цій статті ми представляємо короткий огляд історичних даних про випадки витоків радіонуклідів з приповерхневих могильників радіоактивних відходів. На основі цього огляду можна зробити висновок, що під час оцінки безпеки захоронення ДНАВ на полігонах відходів слід враховувати такі сценарії витоків радіонуклідів і опромінення референтних осіб:

і) вилуговування з відходів в ґрунтові води під впливом атмосферних опадів;

ii) «ефект ванни» (bath-tubing);

iii) сценарії, спричинені екстремальними метеорологічними та гідрологічними явищами (ерозія, затоплення тощо);

iv) втручання людини. Для низки відповідних радіонуклідів таких як C-14, Rn-222 та ін. заслуговує на увагу газоподібний перенос. Крім того, потрібно врахувати можливість ранньої деградації інженерних екранів полігонів (ґрунтове покриття, ізолюючий екран в основі полігона).

Ключові слова: ДНАВ, захоронення відходів, полігони для захоронення відходів, оцінка безпеки, сценарії впливу. 